\title{
Effect of presampling procedures on real-time PCR used for diagnosis of intramammary infections with Staphylococcus aureus in dairy cows at routine milk recordings
}

\author{
Y. S. Mahmmod, ${ }^{*} \dagger^{1}$ I. C. Klaas, ${ }^{*}$ S. S. Nielsen, ${ }^{*}$ J. Katholm, $\ddagger$ and N. Toft ${ }^{*}$ \\ *Department of Large Animal Sciences, Faculty of Health and Medical Sciences, University of Copenhagen, DK-1870 Frederiksberg C, Denmark \\ †Infectious Diseases, Department of Animal Medicine, Faculty of Veterinary Medicine, Zagazig University, Zagazig City 44511, \\ Sharkia Province, Egypt \\ ¥Knowledge Centre for Agriculture, Cattle, Agro Food Park 15, Skejby, DK-8200 Aarhus N, Denmark
}

\begin{abstract}
Aseptic procedures for milk sample collection are considered crucial for bacterial culture to avoid misdiagnosis and subsequently unnecessary treatment or culling. The objective of this field study was to investigate the effect of presampling procedures on the PCR-positivity at cycle threshold value $\leq 37$ of real-time PCR assay to detect Staphylococcus aureus from composite milk samples at routine milk recordings while accounting for known cow-level risk factors. A total of 1,199 dairy cows from 6 herds with conventional milking parlors were sampled and tested by PCR in 2011. Following the farmers' routine premilking preparations, 624 cows of the 1,199 cows were randomly selected for bacterial culture preceded by presampling procedures. These procedures were: cleaning of udder teats, removing the first streams of milk, and $70 \%$ alcohol teat disinfection. Data on parity, somatic cell counts, days in milk, daily milk yield, fat \%, and protein $\%$ were extracted from the Danish Cattle Database, whereas energy-corrected milk was calculated based on the latter 3 . The withinherd prevalence of intramammary infections with Staph. aureus was 31\%, ranging from 16 to $48 \%$ in the 6 herds. Univariable analysis showed that the presampling procedures, somatic cell counts, energy-corrected milk, and days in milk were significantly associated with PCRpositivity, whereas parity was not significant. A multivariable model with herd as random effect showed that presampling procedures decreased the chance of being PCR-positive to 0.75 (95\% CI; 0.58-0.97) compared with cows where the presampling procedures were not carried out. In conclusion, presampling procedures decreased the cow's chance of being PCR-positive to Staph. aureus. Presampling procedures appeared to improve the specificity of PCR for detection of Staph. aureus by reducing false positives through destruction
\end{abstract}

Received August 14, 2012.

Accepted December 10, 2012.

${ }^{1}$ Corresponding author: yasser@sund.ku.dk or yasserpcr@gmail.com of Staph. aureus bacteria colonizing or contaminating the teat skin, orifice, and canal. Random herd effects accounted for only $8.9 \%$, indicating that the cluster effect due to herd management on the PCR positivity to Staph. aureus was virtually negligible.

Key words: presampling procedure, teat disinfection, Staphylococcus aureus, dairy cow

\section{INTRODUCTION}

Staphylococcus aureus is a leading cause of IMI, representing a major agent of contagious bovine mastitis, which is associated with high economic losses (Barkema et al., 2006; Kirchhofer et al., 2007). Cow-level prevalence of Staph. aureus has been reported from clinical and subclinical cases ranging from 3.3 and $5.2 \%$ (Bradley et al., 2007) to 37.5 and $62 \%$ (Gianneechini et al., 2002), respectively. In Denmark, the prevalence of Staph. aureus within 20 dairy herds was 10.2\% (Aarestrup et al., 1995), whereas it ranged from 24 to $34 \%$ with an overall prevalence of $32 \%$ within 57 organic and conventional dairy herds (Bennedsgaard et al., 2006). The estimated cost of mastitis in the United States was $\$ 2.1$ billion in 2007 , where 70 to $80 \%$ of loss was due to subclinical Staph. aureus IMI (Bar et al., 2008).

A high number of teat skin and teat canal bacteria may increase the chance of getting IMI or of being falsely diagnosed as infected when the cow has no IMI. Green and Bradley (2004) reported that Staph. aureus has an ability to survive in the keratin of the teat canal of healthy cows, a substance normally inhibiting bacterial growth. Furthermore, Staph. aureus is known to adhere or colonize strongly to the mammary epithelial cells in large numbers (Frost, 1975; Frost et al., 1977; Ditcham et al., 1996). Consequently, teat skin adherence or colonization may increase the risk of false positives, leading to unnecessary culling or overtreatment with antibiotics. Hence, microbial populations of Staph. aureus on the teat skin or in the teat canal are common, as reported by Haveri et al. (2008). Therefore, sampling procedures are performed to aseptically obtain milk 
samples for bacterial culture (BC), to ensure that the cultured bacteria originate from an IMI and not from contamination or colonization. Thus, decreasing the microbial population of Staph. aureus bacteria on the teat skin or teat canal may reduce the probability of false diagnosis.

Identified cow-level risk factors for IMI with Staph. aureus include parity, milk yield, SCC, DIM, teat lesions or callused teats, protein percentage, and fat percentage (Schukken et al., 1991; Sol et al., 2000; Zadoks et al., 2001; Kivaria et al., 2004; Breen et al., 2009; Michel et al., 2011). The diagnostic used in these studies was based on $\mathrm{BC}$ of one or several consecutive milk samples. However, BC is not completely satisfactory because its overall diagnostic sensitivity for detection of IMI with Staph. aureus from a single quarter milk sample is only $75.5 \%$ (Sears et al., 1990). A single negative culture result is usually not proof that a cow is free of Staph. aureus infection; testing 2 or 3 milk samples collected on different days may be required for accurate diagnosis of infected quarters and determination of a cow's infection status (Sears et al., 1990; Anderson and Pritchard, 2012). Buelow et al. (1996) concluded that bacteriological culture often is insensitive for identification of Staph. aureus IMI based on culturing of 245 quarter milk samples 6 times. Bacterial culture has specific limitations in detection of Staph. aureus due to the intermittent shedding with cycling pattern from infected quarters during lactation (Sears et al., 1990; Walker et al., 2011), which requires consecutive samples for accurate diagnosis of infected quarters. Staphylococcus aureus may also be shed in amounts too low to be detected in the inoculum sample (Buelow et al., 1996; Lam et al., 1996). Moreover, the presence of residual therapeutic antibiotics in the milk sample may inhibit bacterial growth in vitro (Phuektes et al., 2001).

Reliable and rapid methods for the identification of Staph. aureus from milk are crucial for economically sound udder health management. As a faster alternative, PCR has been used for DNA-based direct detection of Staph. aureus in milk (Kim et al., 2001; Ahmadi et al., 2010). Recently, PathoProof Mastitis PCR Assay (Thermo Fisher Scientific, Vantaa, Finland), a multiplex real-time PCR technique, was developed (Koskinen et al., 2009; Friendship et al., 2010). This technique is performed directly on raw or preserved milk samples without the need for BC. The assay is characterized by a higher sensitivity and specificity than BC for detection of Staph. aureus IMI in cow-level and quarter-level milk samples (Taponen et al., 2009; Koskinen et al., 2009). Since 2010, Danish farmers can order cow-level PCR tests (PathoProof Mastitis PCR assay), which are easy to use, less time-consuming, and automatically obtained during routine milk recordings (Katholm, 2010).
The cow-level milk samples are collected after the milking personnel's usual premilking practices, including cleaning of teats and foremilking. In contrast to sampling for $\mathrm{BC}$, no presampling procedures are carried out, including treatment of the teat ends with $70 \%$ alcohol. The objective of this field study was to investigate the effect of presampling procedures on the PCR-positivity at cycle threshold $(\mathbf{C t})$ value $\leq 37$ of real-time PCR assay to detect Staph. aureus from composite milk samples at routine milk recordings while accounting for known cow-level risk factors.

\section{MATERIALS AND METHODS}

\section{Study Population}

Six dairy herds with Danish Holstein cows were selected from 34 Danish dairy herds participating in a project investigating relations between a bulk tank milk (BTM) PCR and the prevalence of Streptococcus agalactiae and Staph. aureus in the herds (J. Katholm, unpublished data). To be eligible for inclusion in the present study, herds had to have a conventional milking parlor system and BTM PCR Ct value $\leq 39$ for Strep. agalactiae and Staph. aureus at the annual PCR testing in October 2010. The cutoff was chosen according to Katholm et al. (2012), as it is a common practice for bulk tank monitoring of Strep. agalactiae in Denmark; 7 herds met the criteria. To confirm that Strep. agalactiae was still a problem in the selected herds, monthly PCR BTM tests were taken from January to March 2011. One herd had a Ct value of 40 in each test and was excluded, whereas the remaining 6 herds had $\mathrm{Ct}$ values of $\leq 37$ in at least 2 out of 3 tests. Information about herd size, sample size per herd, type of milking system, and PCR Ct values from BTM for Strep. agalactiae and Staph. aureus are given in Table 1. The inclusion criteria of PCR Ct value $\leq 39$ was considered to make it highly likely that Strep. agalactiae and Staph. aureus were present in the study herds.

\section{Sample Collection for Real-Time PCR Testing}

Cow-level PCR-samples (composite milk samples) were taken at the routine milk recording between March 28 and May 28, 2011, after the farm personnel had carried out their routine premilking practices. Bronopol-preserved milk samples were taken with the Tru-Test Electronic Milk Meter device (Tru-Test Group Co., Auckland, New Zealand) and delivered to Eurofins Steins Laboratory (Holstebro, Denmark) within $24 \mathrm{~h}$. The composite milk samples were tested using the PathoProof Mastitis PCR assay (Thermo Fisher Scientific). A total of $350 \mu \mathrm{L}$ of milk was used as 
Table 1. Number of lactating dairy cows examined by real-time PCR and cows that received presampling procedures (PSP) for bacterial culture (BC), type of milking parlor, and cycle threshold (Ct) values of bulk tank milk (BTM) PCR testing in 6 Danish dairy herds for Staphylococcus aureus (SA) and Streptococcus agalactiae (GBS)

\begin{tabular}{|c|c|c|c|c|c|c|c|c|}
\hline \multirow{2}{*}{$\begin{array}{l}\text { Herd } \\
\text { code }\end{array}$} & \multirow{2}{*}{$\begin{array}{l}\text { Total no. } \\
\text { of cows } \\
\text { in herd }\end{array}$} & \multirow{2}{*}{$\begin{array}{l}\text { No. of cows } \\
\text { receiving } \\
\text { PSP and BC }\end{array}$} & \multirow{2}{*}{$\begin{array}{l}\text { No. with } \\
\text { complete } \\
\text { records }\end{array}$} & \multirow{2}{*}{$\begin{array}{l}\text { Type of } \\
\text { milking parlor }\end{array}$} & \multicolumn{4}{|c|}{$\mathrm{Ct}$ value of BTM PCR testing } \\
\hline & & & & & \multicolumn{2}{|c|}{ October 2010} & \multicolumn{2}{|c|}{ March 2011} \\
\hline H1 & 146 & 66 & 127 & Herringbone & 34 & 38.2 & 31 & 31 \\
\hline $\mathrm{H} 2$ & 372 & 172 & 317 & Herringbone & 34.6 & 32.1 & 31 & 31 \\
\hline H3 & 177 & 75 & 154 & Herringbone & 33.3 & 27 & 34 & 28 \\
\hline H6 & 187 & 77 & 157 & Herringbone & 31 & 27 & 32 & 28 \\
\hline Total & 1,389 & 609 & 1,199 & & & & & \\
\hline
\end{tabular}

a starting volume for DNA extraction. Cycle threshold values were recorded for all samples and targeting DNA of Staph. aureus; the Ct value represents the number of PCR cycles required to obtain the threshold level (Koskinen et al., 2009). The assay's thermal cycling protocol involved 40 cycles for the reaction. A clear association between $\mathrm{Ct}$ values and the amount of the bacteria was noted; in other words, the higher the amount of bacteria present in the milk sample, the lower the $\mathrm{Ct}$ value obtained with the assay (Koskinen et al., 2008). For example, low Ct values are indicative for higher DNA concentrations of Staph. aureus in the milk sample and vice versa.

\section{Presampling Procedures for Culture Sampling}

Quarter milk samples from 624 cows in the 6 herds were collected for examination by $\mathrm{BC}$ and California Mastitis Test. At the same milking, composite milk samples from all milking cows were tested by PCR. For collection of the samples, each herd was visited by 2 trained technicians from the Danish Cattle Federation. For collection of quarter milk samples for bacteriological testing, approximately $50 \%$ of the cows in each herd were selected using systematic random sampling for the milking unit as follows: in herringbone or side-by-side parlors, the first, third, and fifth unit on the one side were chosen, and the second, forth, and sixth, and so on, from the other side. In the herd using rotary parlors, every second milking unit was chosen.

After farm personnel had carried out their routine premilking practices, quarter milk samples were collected before attachment of the milking device from the randomly selected cows with the following procedure according to the National Mastitis Council recommendations (NMC, 1999). First, the ventral surfaces of udders and teats were cleaned using paper towels. Then, the first 2 or 3 streams of foremilk from each quarter were discarded. Each teat apex was then scrubbed for several seconds with a cotton swab moistened with $70 \%$ alcohol until it was thoroughly clean. Finally, about 5 $\mathrm{mL}$ of milk was collected aseptically from each quarter of each cow in clean, sterile snap-cap plastic tubes and then placed in ice boxes at $5^{\circ} \mathrm{C}$. Ice boxes were delivered to the Eurofins Steins Laboratory within 24 $\mathrm{h}$ of collection for bacterial examination according to Buelow et al. (1996). Information on the farmers' milking practices was gathered in a questionnaire.

\section{Statistical Analysis}

Data on parity, SCC, DIM, daily milk yield, fat percentage, and protein percentage were extracted from the Danish cattle database and merged with the data of presampling procedures and PCR results for Staph. aureus. Energy-corrected milk was calculated based on daily milk yield, fat percentage, and protein percentage, as specified by Sjaunja et al. (1990):

$$
\begin{gathered}
\mathrm{ECM}=\text { milk in } \mathrm{kg} \times(0.122 \times \text { fat } \%) \\
+(0.077 \times \text { protein } \%)+0.249 .
\end{gathered}
$$

Initial exploratory analysis, including summary statistics of dependent and independent variables, was performed followed by hierarchical multivariable modeling. The outcome variable of interest was "PCR-positivity for Staph. aureus" with the explanatory variable of primary interest being presampling procedures while SCC, DIM, ECM, and parity were accounted for in the analysis.

The PCR Ct value was dichotomized based on $\mathrm{Ct}$ value $\leq 37$ (Bexiga et al., 2011). This cutoff for the Ct value was chosen based on the recommendations of the manufacturer of PathoProof Mastitis PCR Assay (Thermo Fisher Scientific). Furthermore, Koskinen et al. (2009), who thoroughly described the details of PCR protocol and Ct values, suggested the same cut- 
off as a demarcation point for differentiation between infected and noninfected samples. The sensitivity and specificity of the PCR at the cutoff for $\mathrm{Ct}$ value $\leq 37$ has been estimated to 91 and $97 \%$, respectively [Y.S. Mahmmod, N. Toft, J. Katholm, C. Grønbæk (Eurofins Steins Laboratory, DK-7500-Holstebro, Denmark), I.C. Klaas, unpublished data]. Presampling procedures were expressed as a dichotomous variable with 2 levels (applied or not applied). Continuous variables were transformed into categorical variables with at least 3 levels for testing the linearity and obtaining a better description of the data. Test day ECM was categorized into 3 levels: low $=<24$; moderate $=\geq 24$ to $<33$; and high $=\geq 33$ based on the upper and lower quartiles. Parity was grouped based on the distribution into first parity, second parity, and third or higher parity. For SCC, no discrete individual cow SCC threshold value was observed that could be used to identify all infected and uninfected cows. Therefore, the results were categorized into 3 levels based on previous studies (Dohoo and Meek, 1982; Jones et al., 1984): low SCC <200,000 cells/mL; moderate SCC $\geq 200,000$ to $<400,000$ cells/ $\mathrm{mL}$; and high $\mathrm{SCC} \geq 400,000$ cells $/ \mathrm{mL}$. Days in milk was categorized into 3 levels based on the stages of lactation that were regarded as high-risk periods (i.e., cows from calving to 90 DIM and cows with more than 300 DIM).

Statistical analyses were carried out using the "glmer" function of R version 2.14.0 (Bates et al., 2011; R Development Core Team, 2011). A generalized hierarchical logistic mixed model was used to run the analysis, where herd was included as a random effect to account for within-herd clustering. A univariable logistic model was used to test the associations between dependent and independent variables. Variables with $P$-value $\leq 0.25$ in the univariable model were offered to the initial final model. The final multivariable model was generated using a Hosmer-Lemeshow strategy (Hosmer and Lemeshow, 2000) and backward elimination by dropping the least significant variable until we got the final model, which included only variables with $P$-value $\leq 0.05$. Biologically reasonable 2 -way interactions between the remaining significant variables in the final model were investigated.

The proportion of the total variance for IMI with Staph. aureus attributable to herds, intraclass correlation coefficient (ICC), was estimated assuming variance at the cow level on the logit scale was $\frac{\pi^{2}}{3}$, with $\pi$ $=3.1416$ (Dohoo et al., 2001); ICC $=\sigma_{h}^{2} /\left(\sigma_{h}^{2}+\frac{\pi^{2}}{3}\right)$, where $\sigma_{h}^{2}$ is the variance at herd level.

\section{RESULTS}

After removing the records of 15 culture-sampled cows with missing PCR results, complete records composed of 1,199 lactating cows were considered for the analysis in the present study (Table 1). Cross tabulation of dependent and independent variables are listed in Tables 2 and 3. The within-herd prevalence of IMI with Staph. aureus was $31 \%$ based on PCR results and ranged from 16 to $48 \%$ for the 6 herds, whereas the within-herd prevalence based on $\mathrm{BC}$ was $25 \%(\mathrm{n}=151)$, ranging from 13 to $33 \%$. The routine milking practices were similar between the 6 herds and can be summarized as follows. The teats were cleaned with individual boiled towels in 5 herds, whereas 1 herd used excelsior wood wool. None of the 6 herds used any premilking teat dips or chemicals, and 5 of the 6 herds used postmilking teat dipping. No specific milking order was used for Staph. aureus-infected cows.

The results of univariable and multivariable logistic regressions are listed in Tables 4 and 5, respectively. Univariable analysis showed that the presampling procedures, SCC, ECM, and DIM were significantly associated with PCR-positivity, whereas parity was not. The resulting final model consisted of the significant variables, presampling procedures, and SCC. Presampling procedures decreased the chance of PCR-positive results to 0.75 (95\% CI: 0.58-0.97) compared with cows where the presampling procedures were not carried out. No interaction between the tested variables was observed. The random effect of herd was 0.32 and accounted for $8.9 \%$ of the total variation.

\section{DISCUSSION}

To our knowledge, this is the first study investigating the effect of presampling procedures on the $\mathrm{Ct}$ values of PCR assays on composite milk samples from routine milk recording. Our findings demonstrated that presampling procedures, in connection with $\mathrm{BC}$, decrease the cow's chance of having a low $\mathrm{Ct}$ value of PCR for Staph. aureus IMI.

\section{Presampling Procedures}

Teat skin, teat canal, and teat orifices are the key points for introduction and invasion of bacterial cells of Staph. aureus, which adhere readily and in large numbers to the ductular epithelial cells of the teats of bovine udder compared with most other bacterial species (Frost, 1975; Frost et al., 1977). Recently, Paduch and Krömker (2011) isolated Staph. aureus from $72.2 \%$ of 1,358 investigated teat canals of clinically 
Table 2. Description and cross tabulation of potential risk factors associated with IMI of Staphylococcus aureus diagnosed by real-time PCR assay in 6 Danish dairy herds

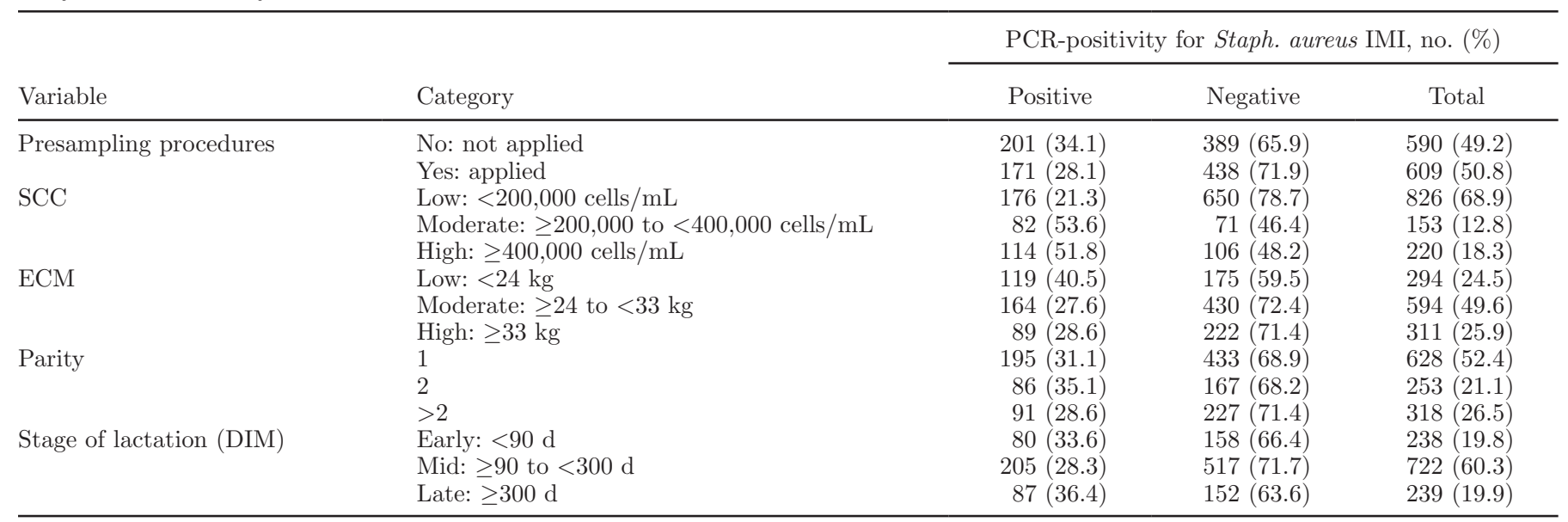

healthy cows. Therefore, presampling procedures can reduce the quantity of Staph. aureus that colonizes or contaminates the teat skin and teat orifice (Bramley et al., 1979). Hence, aseptic procedures for milk sample collection for BC are an absolute necessity.

Regardless of the farmers' premilking practices, our finding demonstrated that the presampling procedures as carried out for $\mathrm{BC}$ reduced the proportion of cows with positive PCR tests for Staph. aureus significantly in the 6 herds. This significant association between performing the presampling procedures and the PCRpositivity to Staph. aureus could be the result of alcohol teat disinfection, the physical effect of discarding the first 2 to 3 streams of milk before sample collection, and the 5 -mL milk sample taken for BC from each quarter.

Alcohol acts by cell dehydration, disruption of cell membranes, and by causing cell protein coagulation. This destroys the bacterial cells of Staph. aureus (Sridhar Rao, 2008; Salvia et al., 2011), which colonize or contaminate the teat orifice or teat skin. Thus, alcohol teat disinfection improves the specificity of PCR for detection of Staph. aureus IMI by reducing false positive results that increase the number of positive cases that are not a true infection, but more likely a contamination.
Discarding the first streams of milk from the teat canal, including the amount taken for the $\mathrm{BC}$ - which includes more bacteria than the rest of the milk-minimizes chances of sample contamination for culture from bacteria located on the teat end (Bewley et al., 2012). It also reduces the quantity of bacterial cells of Staph. aureus that are not adhered to the teat canals (washing/mechanical effect).

\section{Premilking Practices}

Intramammary infection with Staph. aureus of the bovine udder is the culmination of events beginning with contamination or colonization of the teat orifices and the teat skin with the bacterial cells, entry through the teat canal, and establishment of bacterial growth within milk secretory tissue (Larsen et al., 2000; Zecconi, 2006; Barkema et al., 2009). The farm personnel's premilking practices may have reduced the amount of teat skin bacterial cells of Staph. aureus in both groups of cows: those with and without having samples taken for $\mathrm{BC}$.

None of the 6 herds used any premilking teat dips or chemicals with teat disinfecting abilities that could have reduced the amount of Staph. aureus on teat skin,

Table 3. Descriptive statistics of variables included in the analysis for estimation of the effect of presampling procedures on real-time PCR used for diagnosis of IMI with Staphylococcus aureus from dairy cows at routine milk recordings

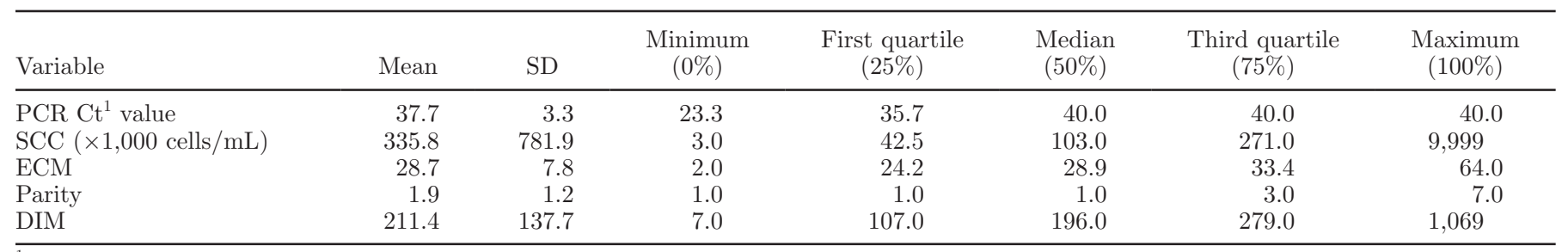

${ }^{1} \mathrm{Ct}=$ cycle threshold. 
Table 4. Univariable random effects logistic regression for risk factors; teat disinfection, stage of lactation (DIM), SCC, parity, and ECM associated with IMI of Staphylococcus aureus diagnosed by real-time PCR assay in 6 Danish dairy herds with the variable herd included as a random effect $(P \leq 0.25)$

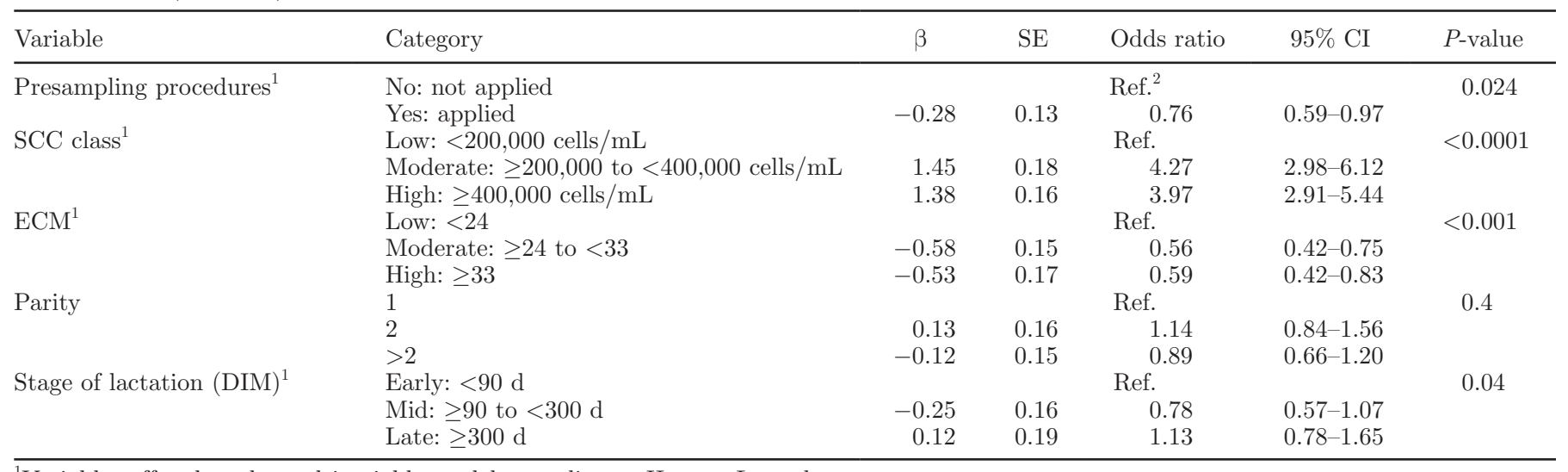

${ }^{1}$ Variables offered to the multivariable model according to Hosmer-Lemeshow strategy.

${ }^{2}$ Ref. $=$ reference value.

the rate of teat canal infections, or the new infection rate with Staph. aureus in general. Pankey et al. (1987) compared the efficacy of premilking teat disinfection by 3 different iodophor compounds with good udder preparation against udder preparation alone. They found that premilking teat disinfection significantly reduced the rate of Staph. aureus IMI by $54 \%$. Clean boiled towels or wood wool were used in the present study, which may have mechanically reduced the amount of Staph. aureus on teat skin. Use of cotton towels for cleaning of teats before milk sampling could efficiently reduce number of bacteria from teat skin. This was demonstrated by Rasmussen et al. (1991), who found that premilking teat preparations using cotton towels for $20 \mathrm{~s}$ are effective to reduce bacteria from teat surfaces because of the physical structure of the towel, physical action on the teat surface, and scrubbing of the teat ends.

Handling of cows before taking PCR milk sample at routine milk recordings could influence the probability of the test being positive. However, the significant association of presampling procedures with PCR-positivity for Staph. aureus could suggest that the bacteria of Staph. aureus on the teat skin, despite postmilking teat dipping or premilking preparation, are either reintro- duced from different unknown sources or the dipping time or disinfectant type is not sufficiently effective to kill the bacteria well or Staph. aureus adheres well to the cells of the upper part of the mammary gland (Frost et al., 1977).

The estimated random herd effects (within-herd ICC) for Staph. aureus was $8.9 \%$. This finding is similar to ICC estimates for Staph. aureus by Barkema et al. (1997). The within-herd ICC could be explained by differences in herd management systems and hygienic measures (Zadoks et al., 2001). However, the finding of a low estimated ICC may indicate that the cluster effect of herd management on the PCR-positivity for Staph. aureus is virtually negligible. This low variation could be explained by similar premilking practices, breeds, conventional milking systems, as well as similar strategies or measures for mastitis control for all the study herds. However, it could also be due to preselection based on BTM PCR results.

In brief, routine premilking cow preparations or practices and postmilking dipping could be important procedures for reduction of the quantity of bacterial cells. However, these procedures are not sufficient to avoid contamination of milk samples collected for PCR testing for Staph. aureus. Therefore, it is recommended

Table 5. Final model: Multivariable random effects logistic analysis for risk factors associated with IMI of Staphylococcus aureus diagnosed by real-time PCR assay in 6 Danish dairy herds with the variable herd included as a random effect $(P \leq 0.05)$

\begin{tabular}{llrrrr}
\hline Variable & Category & $\beta$ & SE & Odds ratio & $95 \%$ CI \\
\hline Presampling procedures & No: not applied & & \multicolumn{2}{c}{ Ref. $^{1}$} \\
& Yes: applied & -0.29 & 0.13 & 0.75 & $0.58-0.97$ \\
SCC class & Low: $<200,000$ cells $/ \mathrm{mL}$ & & & 0.03 \\
& Moderate: $\geq 200,000$ to $<400,000$ cells $/ \mathrm{mL}$ & 1.50 & 0.18 & 4.30 & $3.00-6.18$ \\
& High: $\geq 400,000$ cells $/ \mathrm{mL}$ & 1.38 & 0.16 & 3.97 & $2.90-5.43$ \\
\hline
\end{tabular}

${ }^{1}$ Ref. $=$ reference value. 
the specified presampling procedures (teat cleaning, discarding the first milk streams, and $70 \%$ alcohol teat disinfection) be performed in addition to the other routine milking practices for PCR sampling, as it is recommended for culture-sampling to reduce the number of false positives for PCR results of Staph. aureus. Hence, it is feasible, and even preferable, to perform such procedures at routine DHI recording before sampling for PCR testing for Staph. aureus IMI detection.

The study design used in this study included only PCR sampling after presampling procedures as part of the milk recording scheme, where minute amounts of milk are collected throughout the entire milking process. This design was chosen to mimic the situation in practice. A study design including both pre- and postsampling procedures for PCR testing might have been preferable, but the above-mentioned conditions could not have been mimicked, whereas milk can only be collected for the entire milking once.

\section{CONCLUSIONS}

Our findings demonstrated that presampling procedures, in connection with BC, decrease the cow's chance of having a low Ct value of PCR for Staph. aureus IMI. Presampling procedures may improve the specificity of PCR tests taken at routine milk recording for detection of Staph. aureus IMI by reducing the number of false positives and it should be performed before PCR sampling.

\section{ACKNOWLEDGMENTS}

This research work was funded by Faculty of Health and Medical Sciences, University of Copenhagen. The authors gratefully acknowledge staff of Eurofins Steins Laboratory for providing the laboratory space to conduct this research and for their technical and logistic support. The authors thank Knowledge Centre for Agriculture, Cattle, for funding of PCR testing and the technicians for their support in sample collection. Thanks to the Danish farmers for their patience and making their cows available for our study.

\section{REFERENCES}

Aarestrup, F. M., H. C. Wegener, V. T. Rosdahl, and N. E. Jensen. 1995. Staphylococcal and other bacterial species associated with intramammary infections in Danish dairy herds. Acta Vet. Scand. $36: 475-487$.

Ahmadi, M., S. M. R. Rohani, and N. Ayremlou. 2010. Detection of Staphylococcus aureus in milk by PCR. Comp. Clin. Pathol. 19:91-94.

Anderson, K. L., and D. E. Pritchard. 2012. An update on Staphylococcus aureus mastitis. Accessed May 15, 2012. http://www.cals.ncsu. edu/an_sci/extension/dairy/newsletters/0403nlet.PDF.
Bar, D., L. W. Tauer, G. Bennett, R. N. González, J. A. Hertl, Y. H. Schukken, H. F. Schulte, F. L. Welcome, and Y. T. Gröhn. 2008. The cost of generic clinical mastitis in dairy cows as estimated by using dynamic programming. J. Dairy Sci. 91:2205-2214.

Barkema, H. W., M. J. Green, A. J. Bradley, and R. N. Zadoks. 2009. Invited review: The role of contagious disease in udder health. J. Dairy Sci. 92:4717-4729.

Barkema, H. W., Y. H. Schukken, T. J. Lam, D. T. Galligan, M. L. Beiboer, and A. Brand. 1997. Estimation of interdependence among quarters of the bovine udder with subclinical mastitis and implications for analysis. J. Dairy Sci. 80:1592-1599.

Barkema, H. W., Y. H. Schukken, and R. N. Zadoks. 2006. Invited review: The role of cow, pathogen, and treatment regimen in the therapeutic success of bovine Staphylococcus aureus mastitis. J. Dairy Sci. 89:1877-1895.

Bates, D., M. Maechler, and B. Bolker. 2011. lme4: Linear mixedeffects models using S4 classes. R package version 0.999375-42. Accessed May 23, 2012. http://CRAN.R-project.org/package=lme4.

Bennedsgaard, T. W., S. M. Thamsborg, F. M. Aarestrup, C. Enevoldsen, M. Vaarst, and A. B. Christoffersen. 2006. Resistance to penicillin of Staphylococcus aureus isolates from cows with high somatic cell counts in organic and conventional dairy herds in Denmark. Acta Vet. Scand. 48:24.

Bewley, J. M., R. J. Harmon, and S. Locke. 2012. Collection and preparation of milk samples for microbiological culturing. Accessed Jan. 23, 2013. http://www.extension.org/pages/28320/collectionand-preparation-of-milk-samples-for-microbiological-culturing.

Bexiga, R., M. T. Koskinen, J. Holopainen, C. Carneiro, H. Pereira, K. A. Ellis, and C. L. Vilela. 2011. Diagnosis of intramammary infection in samples yielding negative results or minor pathogens in conventional bacterial culturing. J. Dairy Res. 78:49-55.

Bradley, A. J., K. A. Leach, J. E. Breen, L. E. Green, and M. J. Green. 2007. Survey on the incidence and aetiology of mastitis on dairy farms in England and Wales. Vet. Rec. 160:253-257.

Bramley, A. J., J. S. King, T. M. Higgs, and F. K. Neave. 1979. Colonization of the bovine teat duct following inoculation with Staphylococcus aureus and Escherichia coli. Br. Vet. J. 135:149-162.

Breen, J. E., M. J. Green, and A. J. Bradley. 2009. Quarter and cow risk factors associated with the occurrence of clinical mastitis in dairy cows in the United Kingdom. J. Dairy Sci. 92:2551-2561.

Buelow, K. L., C. B. Thomas, W. J. Goodger, K. V. Nordlund, and M. T. Collins. 1996. Effect of milk sample collection strategy on the sensitivity and specificity of bacteriologic culture and somatic cell count for detection of Staphylococcus aureus intramammary infection in dairy cattle. Prev. Vet. Med. 26:1-8.

Ditcham, W. G., J. A. Leigh, A. P. Bland, and A. W. Hill. 1996. Adhesion of Streptococcus uberis to monolayers of cultured epithelial cells derived from the bovine mammary gland. FEMS Immunol. Med. Microbiol. 14:145-150.

Dohoo, I. R., and A. H. Meek. 1982. Somatic cell counts in bovine milk. Can. Vet. J. 23:119-125.

Dohoo, I. R., E. Tillard, H. Stryhn, and B. Faye. 2001. The use of multilevel models to evaluate sources of variation in reproductive performance in dairy cattle in Reunion Island. Prev. Vet. Med. 50:127-144.

Friendship, C., D. Kelton, D. van de Water, D. Slavic, and M. T. Koskinen. 2010. Field evaluation of the Pathoproof mastitis PCR assay for the detection of Staphylococcus aureus infected cows using DHI samples. Pages 226-227 in NMC 49th Annual Meeting Proceedings. National Mastitis Council (NMC), Madison, WI.

Frost, A. J. 1975. Selective adhesion of microorganisms to the ductular epithelium of the bovine mammary gland. Infect. Immun. 12:1154-1156.

Frost, A. J., D. D. Wanasinghe, and J. B. Woolcock. 1977. Some factors affecting selective adherence of microorganisms in the bovine mammary gland. Infect. Immun. 15:245-253.

Gianneechini, R., C. Concha, R. Rivero, I. Delucci, and J. M. Lopez. 2002. Occurrence of clinical and sub-clinical mastitis in dairy herds in the west littoral region in Uruguay. Acta Vet. Scand. $43: 221-230$. 
Green, M., and A. Bradley. 2004. Clinical Forum: Staphylococcus aureus mastitis in cattle. Cattle practice. 9:1-9. Accessed May 15, 2012. http://ovg.co.uk/Staph\%20aureus\%20mastitis\%20in\%20 cattle.pdf.

Haveri, M., M. Hovinen, A. Roslöf, and S. Pyörälä. 2008. Molecular types and genetic profiles of Staphylococcus aureus strains isolated from bovine intramammary infections and extramammary sites. J. Clin. Microbiol. 46:3728-3735.

Hosmer, D. W., and S. Lemeshow. 2000. Applied Logistic Regression. John Wiley \& Sons Inc., New York, NY.

Jones, G. M., R. E. Pearson, G. A. Clabaugh, and C. W. Heald. 1984. Relationships between somatic cell counts and milk production. J. Dairy Sci. 67:1823-1831.

Katholm, J. 2010. Streptococcus agalactiae in the Nordic countries. Proc. Veterinärkongressen Uppsala, Sweden 11-12:77-80.

Katholm, J., T. W. Bennedsgaard, M. T. Koskinen, and E. Rattenborg. 2012. Quality of bulk tank milk samples from Danish dairy herds based on real-time polymerase chain reaction identification of mastitis pathogens. J. Dairy Sci. 95:5702-5708.

Kim, C. H., M. A. Khan, E. Morin, W. L. Hurley, D. N. Tripathy, M. J. Kehrli, A. O. Olouch, and I. Kakomal. 2001. Optimization of the PCR for detection of Staphylococcus aureus nuc gene in bovine milk. J. Dairy Sci. 84:74-83.

Kirchhofer, M., L. Tavel, D. Strabel, C. Fournier, A. Steiner, H. U. Graber, and T. Kaufmann. 2007. Herd problem: Udder health. Retrospective study of farms with udder health problems assessed by the Swiss Bovine Health Service (BHS) from 1999 to 2004. Dtsch. Tierarztl. Wochenschr. 117:338-344.

Kivaria, F. M., J. P. Noordhuizen, and A. M. Kapaga. 2004. Risk indicators associated with subclinical mastitis in smallholder dairy cows in Tanzania. Trop. Anim. Health Prod. 36:581-592.

Koskinen, M. T., J. Holopainen, S. Pyorala, P. Bredbacka, A. Pitkala, H. W. Barkema, R. Bexiga, J. Roberson, L. Solverod, R. Piccinini, D. Kelton, H. Lehmusto, S. Niskala, and L. Salmikivi. 2009. Analytical specificity and sensitivity of a real-time PCR assay for identification of bovine mastitis pathogens. J. Dairy Sci. 92:952-959.

Koskinen, M. T., J. Holopainen, L. Salmikivi, H. Lehmusto, S. Niskala, and J. Kurkela. 2008. Analytic detection limit of the PathoProof Mastitis PCR assay determined using two different experimental approaches. Pages 183-189 in Proc. Int. Conf. Mastitis ControlFrom Science to Practice. Wageningen Academic Publishers, Wageningen, the Netherlands.

Lam, T. J. G. M., L. J. A. Lipman, Y. H. Schukken, W. Gaastra, and A. Brand. 1996. Epidemiological characteristics of bovine clinical mastitis caused by Staphylococcus aureus and Escherichia coli studies by DNA fingerprinting. Am. J. Vet. Res. 57:39-42.

Larsen, H. D., K. H. Sloth, C. Elsberg, C. Enevoldsen, L. H. Pedersen, N. H. R. Eriksen, F. M. Aarestrup, and N. E. Jensen. 2000. The dynamics of Staphylococcus aureus intramammary infection in nine Danish dairy herds. Vet. Microbiol. 71:89-101.

Michel, A., C. Syring, A. Steiner, and H. U. Graber. 2011. Intramammary infections with the contagious Staphylococcus aureus genotype B in Swiss dairy cows are associated with low prevalence of coagulase-negative staphylococci and Streptococcus spp. Vet. J. 188:313-317.
NMC. 1999. Laboratory Handbook on Bovine Mastitis. National Mastitis Council (NMC), Madison, WI.

Paduch, J. H., and V. Krömker. 2011. Colonization of the teat skin and the teat canal by mastitis pathogens in dairy cattle. Tierarztl. Prax. Ausg. G Grosstiere Nutztiere 39:71-76.

Pankey, J. W., E. E. Wildman, P. A. Drechsler, and J. S. Hogan. 1987. Field trial evaluation of premilking teat disinfection. J. Dairy Sci. 70:867-872.

Phuektes, P., P. D. Mansell, and G. F. Browning. 2001. Multiplex polymerase chain reaction assay for simultaneous detection of Staphylococcus aureus and streptococcal causes of bovine mastitis. J. Dairy Sci. 84:1140-1148.

R Development Core Team. 2011. R: A Language and Environment for Statistical Computing. R Foundation for Statistical Computing, Vienna, Austria. http://www.R-project.org.

Rasmussen, M. D., D. M. Galton, and L. G. Petersson. 1991. Effects of premilking teat preparation on spores of anaerobes, bacteria, and iodine residues in milk. J. Dairy Sci. 74:2472-2478.

Salvia, A. C. R. D., G. R. Teodoro, I. Balducci, C. Y. KogaIto, and S. H. G. de Oliveira. 2011. Effectiveness of $2 \%$ peracetic acid for the disinfection of gutta-percha cones. Braz. Oral Res. 25:23-27.

Schukken, Y. H., F. J. Grommers, D. van de Geer, H. N. Erb, and A Brand. 1991. Risk factors for clinical mastitis in herds with a low bulk milk somatic cell count. 2. Risk factors for Escherichia coli and Staphylococcus aureus. J. Dairy Sci. 74:826-832.

Sears, P. M., B. S. Smith, P. B. English, P. S. Herer, and R. N. Gonzalez. 1990. Shedding pattern of Staphylococcus aureus from bovine intramammary infections. J. Dairy Sci. 73:2785-2789.

Sjaunja, L. O., L. Baevre, L. Junkkarinen, J. Pedersen, and J. Setala. 1990. A Nordic proposal for an energy-corrected milk (ECM) formula. Pages 156-157 in Performance Recording of Animals: State of the Art 1990. EAAP Publication No. 50, Centre for Agricultural Publishing and Documentation, Wageningen, the Netherlands.

Sol, J., O. C. Sampimon, H. W. Barkema, and Y. H. Schukken. 2000. Factors associated with cure after therapy of clinical mastitis caused by Staphylococcus aureus. J. Dairy Sci. 83:278-284.

Sridhar Rao, P. N. 2008. Sterilization and disinfection. Accessed Apr. 27, 2012. http://www.microrao.com/micronotes/sterilization.pdf.

Taponen, S., L. Salmikivi, H. Simojoki, M. T. Koskinen, and S. Pyörälä. 2009. Real-time polymerase chain reaction-based identification of bacteria in milk samples from bovine clinical mastitis with no growth in conventional culturing. J. Dairy Sci. 92:26102617.

Walker, J. B., P. J. Rajala-Schultz, W. L. Walker, J. L. Mathews, W. A. Gebreyes, and F. J. DeGraves. 2011. Variation in daily shedding patterns of Staphylococcus aureus in naturally occurring intramammary infections. J. Vet. Diagn. Invest. 23:1114-1122.

Zadoks, R. N., H. G. Allore, H. W. Barkema, O. C. Sampimon, G. J. Wellenberg, Y. T. Grohn, and Y. H. Schukken. 2001. Cow-and quarter-level risk factors for Streptococcus uberis and Staphylococcus aureus mastitis. J. Dairy Sci. 84:2649-2663.

Zecconi, A. 2006. Can we eradicate Staphylococcus aureus mastitis? WBC_2006, Nice, France. Accessed Jan. 22, 2013. http://www. ivis.org/proceedings/wbc/wbc2006/zecconi.pdf. 